\title{
西
} physics

Journal Homepage https://www.ejournal.unib.ac.id/index.php/nmj

\section{Studi Awal Analisis Variasi Massa Jahe Terhadap Daya Listrik}

\author{
Sri Endang Wahyuni*, Fita Widiyatun, Didik Nur Huda
}

Fakultas Teknik dan IImu Komputer, Universitas Indraprasta PGRI, Indonesia

\section{ARTICLE INFO}

Riwayat Artikel:

Draft diterima: 29 November 2020

Revisi diterima: 20 Desember 2020

Diterima: 23 Desember 2020

Tersedia Online: 26 Desember 2020

*Corresponding author:

sherie.endang.wahyuni@gmail.com

\begin{abstract}
ABSTRAK
Baterai merupakan salah satu sumber energi listrik yang sangat banyak penggunaanya. Khususnya dalam menyokong aktivitas sehari-hari seperti alat-alat elektronik, penerangan, jam, mainan dan peralatan lainnya. Baterai yang saat ini ada dipasaran mengandung logam berat sehingga limbahnya berbahaya bagi lingkungan. Berbagai jenis energi listrik alternatif telah berkembang untuk mencari baterai yang ramah lingkungan di antaranya biobaterai. Penelitian mengenai bahan biobaterai dari jahe bertujuan untuk melihat potensi listrik alam pada Jahe. Metode yang digunakan adalah pengukuran langsung nilai tegangan dan arus menggunakan multimeter. Tiga jenis jahe yang digunakan yaitu jahe gajah, jahe emprit dan jahe merah. Selain itu dilakukan variasi massa pada jahe sebesar 100 gram, 200 gram, dan 300 gram untuk melihat pengaruh terhadap nilai tegangan, arus dan daya maksimum yang dihasilkan. Hasil penelitian menunjukan bahwa semakin bertambahnya massa jahe maka bertambah pula daya listrik yang dihasilkan. Dari ketiga jenis jahe diperoleh nilai daya tertinggi yaitu pada jahe gajah dengan massa 300 gram sebesar 1,841 x 10-2 Watt dengan tegangan sebesar 0,46 Volt dan arus $4 \times 10^{-5} \mathrm{~A}$. Dari ketiga jahe yang dianalisis memiliki potensi adanya tegangan dan arus listrik, sehingga dapat dikembangkan sebagai bio baterai.
\end{abstract}

Kata kunci: Biobaterai, Jahe, Tegangan, Daya Maksimum.

\begin{abstract}
The battery is one of the most widely used sources of electrical energy. Especially in supporting daily activities such as electronic devices, lighting, clocks, toys and other equipment. Batteries currently on the market contain heavy metals so their waste is harmful to the environment. Various types of alternative electrical energy have developed to look for environmentally friendly batteries, including biobatteries. Research on biobattery materials from ginger aims to see the natural electrical potential of ginger. The method used is direct measurement of voltage and current values using a multimeter. Three types of ginger are used, namely elephant ginger, emprit ginger and red ginger. In addition, the mass variation of ginger is 100 grams, 200 grams, and 300 grams to see the effect on the value of the voltage, current and maximum power generated. The results showed that the increasing mass of ginger, the increased electrical power produced. Of the three types of ginger, the highest power value was obtained, namely elephant ginger with a mass of 300 grams of $1,841 \times 10-2$ Watt with a voltage of 0.46 Volts and a current of $4 \times 10^{-5} \mathrm{~A}$. Of the three ginger analyzed, it has the potential for voltage and electric current, so it can be developed as a bio battery.
\end{abstract}

Keywords: Biobattery, Ginger, Voltage, Maximum Power. 


\section{PENDAHULUAN}

Baterai merupakan salah satu media yang dapat menyimpan energi listrik dan banyak dimanfaatkan oleh manusia sebagai kebutuhan pokok. Beragam penggunaan baterai dalam kehidupan kita misal untuk handphone, laptop, menggerakan mainan anak-anak, menghidupkan remote tv dan jam dinding. Baterai terbuat dari zink sebagai anoda, karbon sebagai katoda dan elektrolit yang dipakai berupa pasta campuran $\mathrm{MnO}_{2}$, serbuk karbon dan $\mathrm{NH}_{4} \mathrm{Cl}$ [1]. Baterai yang dijual dipasaran, yang kita gunakan saat ini mengandung logam berat seperti merkuri, mangan, timbal, kadmium, nikel dan lithium, yang berbahaya bagi lingkungan dan kesehatan [2]. Setelah baterai selesai digunakan, kebanyakan orang akan membuangnya ketempat sampah atau sembarang. Padahal limbah baterai termasuk dalam Sampah bahan berbahaya dan beracun rumah tangga (SB3-RT) yang apabila tidak dikelola dengan baik akan berpotensi menyebabkan risiko terhadap keselamatan dan kesehatan [3]. Banyak dampak negatif dari logam - logam berat yang terkandung pada baterai yang ada dipasaran, maka dari itu perlu dikembangkan baterai ramah lingkungan.

Biobaterai adalah penyimpan perangkat energi yang di dukung oleh senyawa organik, biasanya menjadi glukosa dalam [4]. Bio baterai bisa menjadi alternatif baterai yang ramah lingkungan karena bahannya yang terdapat dialam. Pada Beberapa penelitian biobaterai sudah banyak dikembangkan diantaranya penelitian Khaeriah dan Destini (2017) mengenai analisis kelistrikan pasta elektrolit limbah kulit durian sebagai biobaterai. Dimana kulit durian memiliki kandungan zat kalium natrium mangan asam folat tinggi untuk mengalirkan ion positif dan negatif. Kandungan inilah yang kemudian menciptakan aliran listrik. Penelitian lainnya oleh Pulungan, dkk. (2017) mengenai pembuatan bio baterai berbahan dasar kulit pisang. Pada prosesnya dibutuhkan 5 gram kulit pisang untuk setiap batu baterai. kemudian kulit pisang dibuat sebagai pasta dan diukur nilai tegangan dan daya tahan bio baterai yang terbuat dari pasta pisang. Selain itu Pamungkas berhasil membuat biolistrik dari kentang dengan penambahan enzim ptialin sebagai pengoptimal arus [1]. Dengan adanya bahan organik diharapkan dapat menghasilkan baterai yang ramah lingkungan. Tidak hanya dari kentang, tanaman jahe juga diteliti oleh Putra mengenai studi eletroda berbahan dasar jahe untuk aplikasi superkapasitor elektrokimia [7].

Penulis telah melakukan penelitian awal pada rimpang jahe sebagai bahan biobaterai. Bertujuan untuk mengetahui potensi listrik alam pada jahe. saat ini bahan yang terdapat di alam dan dimudah dikembangbiakan yaitu Jahe (Zingiber officinalle). Beberapa peneliti dari Pakistan telah meneliti beberapa kandungan mineral yang terdapat didalam tanaman jahe (Zingiber officinale) diantaranya seng, mangan, besi, dan tembaga. Dimana nilai-nilai kandungan yang terdapat pada jahe (Zingiber officinale) yaitu seng sebesar $>50 \mu \mathrm{g} \mathrm{g}^{-1}$, mangan sebesar $>200 \mu \mathrm{g} \mathrm{g}^{-1}$, tembaga sebesar $>50 \mu \mathrm{g} \mathrm{g}^{-1}$, dan besi sebesar $>400 \mu \mathrm{g} \mathrm{g}{ }^{-1}$ [8]. Salah satu logam yang memiliki nilai ekonomis adalah mangan. Logam mangan digunakan sebagai campuran logam, misalnya pada baja feromangan, mangan oksida digunakan sebagai bahan depolarisator baterai kering [9]. Diharapkan kandungan mineral pada jahe dapat mengalirkan ion positif dan negatif sehingga berpotensi aliran listrik yang kedepannya bisa di aplikasikan sebagai biobaterai.

\section{METODE PENELITIAN}

Penelitian ini dilakukan di laboratorium Pendidikan Fisika Universitas Indraprasta PGRI. Dimulai bulan Oktober - November 2020. Penelitian ini melibatkan dua variabel yaitu variabel bebas terdiri dari variasi massa pada masing-masing Jahe yaitu 100 gram, 200 gram dan 300 gram dan variabel terikat yang terdiri dari tegangan dan arus listrik. Adapun alat-alat yang digunakan dalam pengambilan data yaitu multimeter, kabel, capit buaya, timbangan/neraca dan paku. Bahan yang digunakan yaitu Jahe emprit, jahe gajah dan jahe merah.

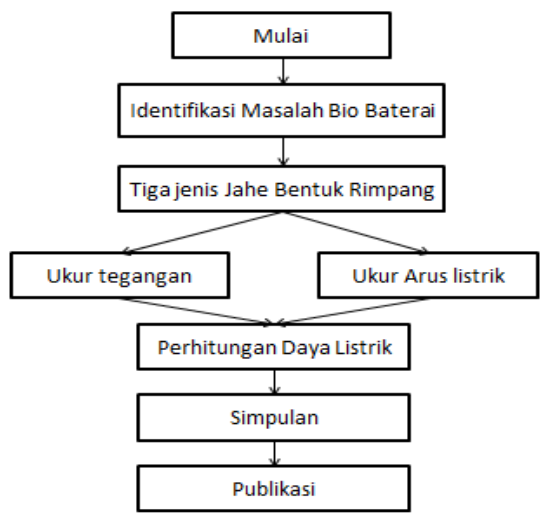

Gambar 1. Diagram alir penelitian 


\section{Teknik pengumpulan data}

Data yang di ukur dalam penelitian ini adalah tegangan dan arus listrik yang dihasilkan dari rimpang jahe yang diukur secara langsung. Adapun langkah pengukuran rimpang jahe secara langsung yaitu:

1. Menyiapkan alat dan bahan.

2. Melakukan kalibrasi pada alat yang akan digunakan seperti multimeter dan timbangan.

3. Timbanglah jahe emprit, jahe gajah dan jahe merah masing-masing dengan variasi massa 100 gram, 200 gram dan 300 gram.

4. Siapkan capit buaya, kabel dan paku sebagai anoda dan katoda untuk di tusukan ke rimpang jahe

5. Mengukur tegangan dan arus listrik yang terbaca di mulitimeter dan mencatat setiap perubahan arus setiap waktu.

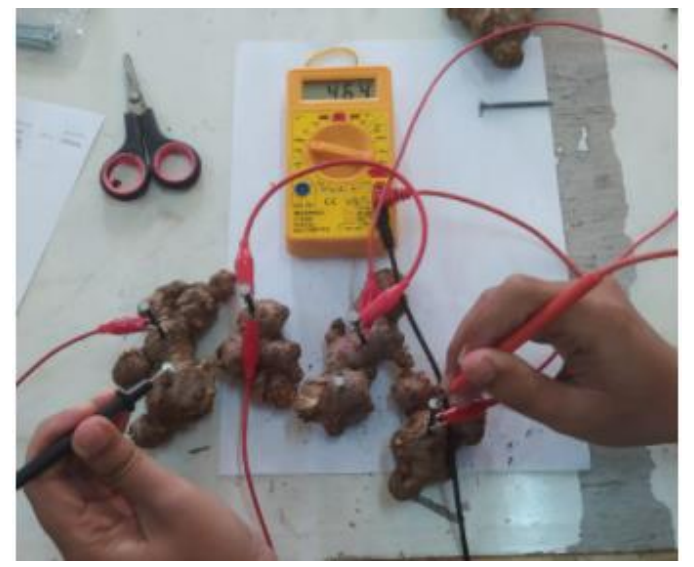

Gambar 2. Pengukuran Tegangan dan Kuat Arus Listrik pada Rimpang Jahe.

\section{Teknik Analisis Data}

Dari hasil pengukuran dari ketiga jenis rimpang jahe secara langsung terbaca di multimeter nilai tegangan $(V)$ dan arus listrik (I). Kemudian dilakukan perhitungan daya listrik menggunakan Microsoft Excel 2010 yang dihasilkan masing - masing jahe dengan variasi massa. Adapun rumus perhitungan daya listrik sebagai berikut :

$$
P=V I=
$$

Keterangan :

$P=$ Daya listrik (Watt)

$V=$ Tegangan (Volt)

$I=$ Kuat arus listrik (Ampere)

\section{HASIL DAN PEMBAHASAN}

Pengolahan Data yang diperoleh dari hasil penelitian disajikan dalam bentuk tabel dan histogram pada Microsoft excel 2010. Data hasil pengukuran tegangan listrik dari ketiga jenis jahe dengan memvariasikan massa dapat diperlihatkan pada Table 1 dan Gambar 3.

Tabel 1. Hasil pengukuran tegangan $(V)$ rata-rata

\begin{tabular}{|c|l|l|l|l|}
\hline No. & & \multicolumn{3}{|c|}{ Tegangan (volt) } \\
\hline & $\begin{array}{c}\text { Massa } \\
\text { (gram) }\end{array}$ & $\begin{array}{c}\text { Jahe } \\
\text { emprit }\end{array}$ & $\begin{array}{c}\text { Jahe } \\
\text { gajah }\end{array}$ & $\begin{array}{c}\text { Jahe } \\
\text { merah }\end{array}$ \\
\hline 1. & 100 & 0,457 & 0,456 & 0,469 \\
\hline 2. & 200 & 0,428 & 0,430 & 0,465 \\
\hline 3. & 300 & 0,421 & 0,458 & 0,412 \\
\hline
\end{tabular}




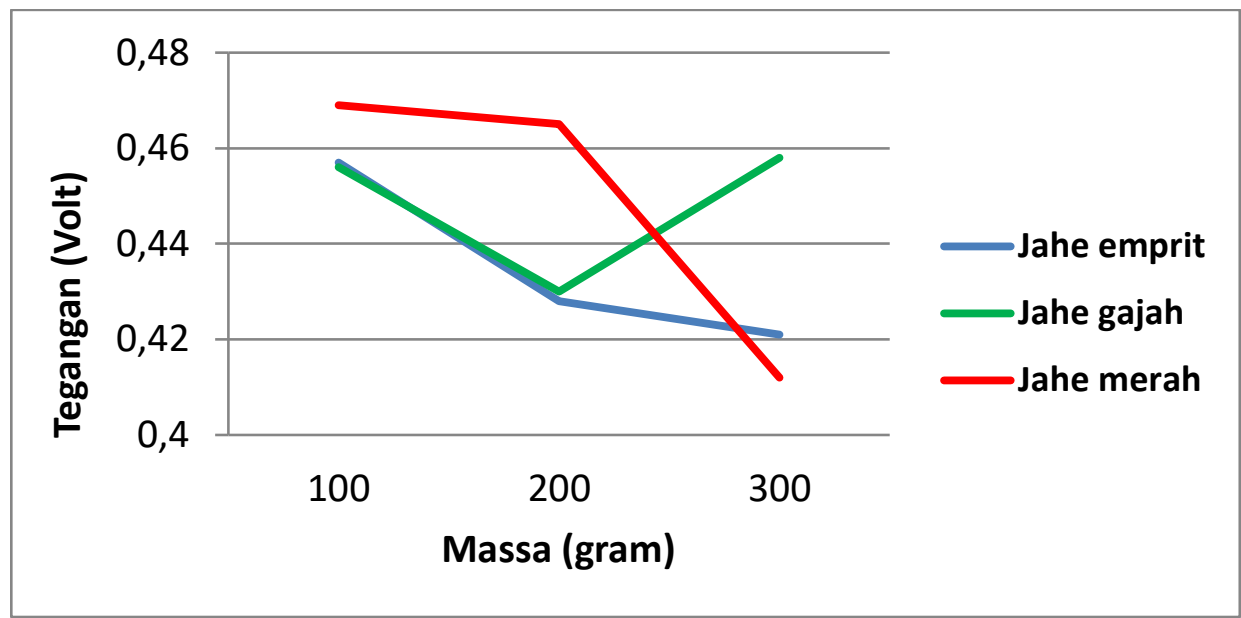

Gambar 3. Grafik hubungan massa dengan tegangan, beberapa jenis jahe

Pada hasil tegangan rerata tertinggi diperoleh pada rimpang jahe merah bermassa 100 gr dengan nilai 0,469 $\mathrm{V}$. Rimpang jahe merah semakin massa bertambah rerata tegangan semakin menurun, akan tetapi ini belum bisa membuktikan bahwa linieritas antara massa dengan tegangan. Rimpang jahe emprit menghasilkan tegangannya semakin kecil dari massa yang semakin bertambah. Rimpang jahe gajah pada massa $100 \mathrm{gr}$ dan $300 \mathrm{gr}$ tegangannya lebih tinggi dibandingkan dengan massa $200 \mathrm{gr}$. Dari rimpang jahe gajah inilah alasan belum terdapat linieritas antara massa dan tegangan yang dihasilkan.

Selanjutnya, pada proses awal pengukuran nilai arus yang terbaca di multimeter berubah-ubah sampai pada nilai arus yang stabil, maka data nilai arus akan dicatat. Data hasil pengukuran arus dapat diperlihatkan pada Table 2 dan Gambar 4. Kuat arus listrik yang dihasilkan dari beberapa rimpang jahe, dua buah jahe yaitu jahe gajah dan jahe merah mengalami kenaikan kuat arus listrik seiring bertambahnya massa, akan tetapi tidak terlalu signifikan. Sedangkan pada rimpang jahe emprit tidak mengalami perubahan yang berarti. Orde arus listrik yang dihasilkan cukup kecil yaitu orde $\mu A\left(1 \mu A=10^{-6} A\right)$ dalam alat ukur.

Tabel 2. Hasil pengukuran Arus (I) rata-rata

\begin{tabular}{|c|r|c|c|c|}
\hline No. & & \multicolumn{3}{|c|}{ Arus Listrik (Ampre) } \\
\hline & $\begin{array}{c}\text { Massa } \\
\text { (gram) }\end{array}$ & $\begin{array}{c}\text { Jahe } \\
\text { emprit }\end{array}$ & $\begin{array}{c}\text { Jahe } \\
\text { gajah }\end{array}$ & $\begin{array}{c}\text { Jahe } \\
\text { merah }\end{array}$ \\
\hline 1. & 100 & $3,10 \mathrm{E}-05$ & $2,00 \mathrm{E}-05$ & $3,10 \mathrm{E}-05$ \\
\hline 2. & 200 & $3,10 \mathrm{E}-05$ & $4,00 \mathrm{E}-05$ & $3,10 \mathrm{E}-05$ \\
\hline 3. & 300 & $3,10 \mathrm{E}-05$ & $4,00 \mathrm{E}-05$ & $4,00 \mathrm{E}-05$ \\
\hline
\end{tabular}

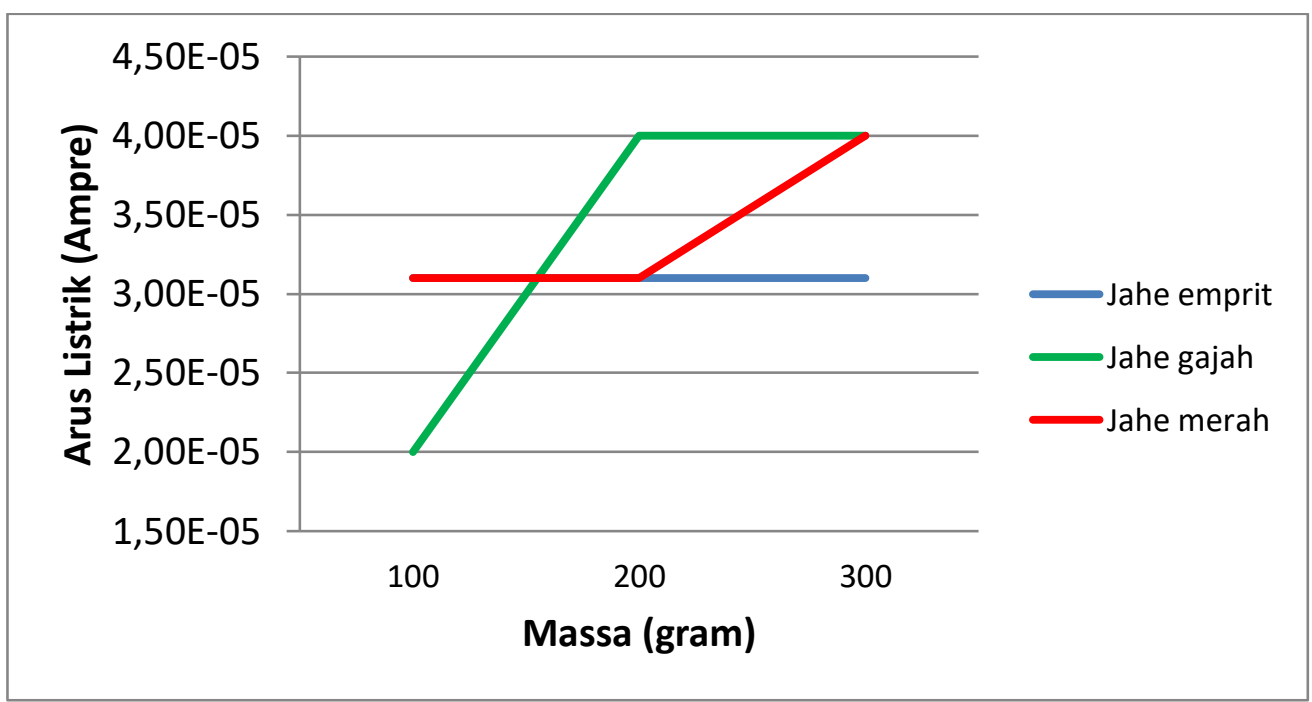

Gambar 4. Grafik hubungan massa dengan arus listrik, beberapa jenis jahe 
Dari hasil tegangan dan kuat arus listrik yang diperoleh lalu dihitung daya listrik yang dihasilkan menggunakan persamaan 1. Hasil yang diperoleh tertera pada Tabel 3. Dari hasil yang diperoleh rimpang jahe gajah mengalami perubahan daya listrik paling signifikan dibanding dengan yang lain (Gambar 5.)

Tabel 3. Hasil perhitungan daya listrik

\begin{tabular}{|c|r|c|c|c|}
\hline No. & & \multicolumn{3}{|c|}{ Daya listrik (Watt) } \\
\hline & $\begin{array}{c}\text { Massa } \\
\text { (gram) }\end{array}$ & $\begin{array}{c}\text { Jahe } \\
\text { emprit }\end{array}$ & $\begin{array}{c}\text { Jahe } \\
\text { gajah }\end{array}$ & $\begin{array}{c}\text { Jahe } \\
\text { merah }\end{array}$ \\
\hline 1. & 100 & $1,43 \mathrm{E}-02$ & $8,80 \mathrm{E}-03$ & $1,46 \mathrm{E}-02$ \\
\hline 2. & 200 & $1,33 \mathrm{E}-02$ & $1,56 \mathrm{E}-02$ & $1,44 \mathrm{E}-02$ \\
\hline 3. & 300 & $1,32 \mathrm{E}-02$ & $1,84 \mathrm{E}-02$ & $1,53 \mathrm{E}-02$ \\
\hline
\end{tabular}

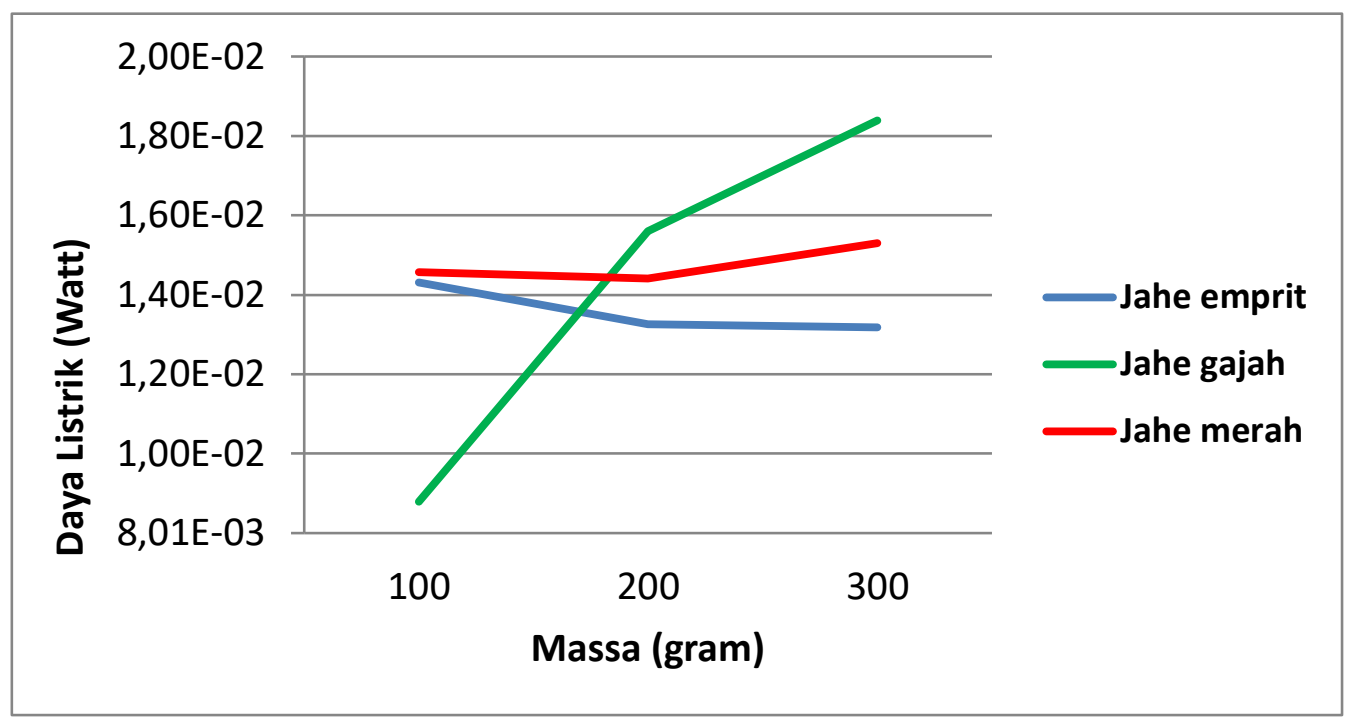

Gambar 5. Grafik hubungan massa dengan daya listrik, beberapa jenis jahe

Dari perbandingan beberapa besaran yang diukur peneliti rimpang jahe gajah menghasilkan daya listrik tertinggi diperoleh pada rimpang jahe gajah dengan nilai $1,841 \times 10^{-2} \mathrm{~W}$ dengan massa 300 gram. Sedangkan rimpang jahe yang lain daya listrik yang dihasilkan jahe merah tertinggi pada massa 300 gram dengan daya $1,531 \times 10^{-2} \mathrm{~W}$ dan rimpang jahe emprit $1,432 \times 10^{-2} \mathrm{~W}$ pada massa $100 \mathrm{gram}$. Hal ini dikarenakan rimpang jahe gajah memiliki kandungan air yang lebih banyak, sehingga rimpang jahe gajah lebih elektrolit dibandingkan rimpang jahe yang lain. Hal ini juga membuat hubungan linier antara massa dengan daya listrik.

\section{KESIMPULAN}

Variasi massa pada ketiga jenis rimpang jahe terhadap nilai tegangan listrik yang dihasilkan belum terdapat linieritas. Variasi massa pada ketiga jenis rimpang jahe terhadap nilai arus listrik yang dihasilkan mengalami kenaikan kuat arus listrik seiring bertambahnya massa, akan tetapi tidak terlalu signifikan. Variasi massa pada ketiga rimpang jahe terdapat linearitas terhadap daya listrik. sehingga dapat disimpulkan bahwa dari ketiga jahe yang dianalisis menghasilkan tegangan dan arus listrik sehingga berpotensi menjadi biobaterai yang ramah lingkungan.

\section{UCAPAN TERIMAKASIH}

Penulis mengucapkan Terimakasih kepada ketua LPPM UNINDRA, Ketua Program studi Informatika, Asisten Laboratorium Pendidikan Fisika UNINDRA dan Tim Peneliti atas dukungan dalam menyelesaikan penelitian.

\section{REFERENSI}

[1] S. Pamungkas, "Kentang Sebagai Bio Listrik dengan Penambahan Enzim Ptialin Sebagai Pengoptimal Arus," Pancasakti Sci. Educ. J., vol. 2, no. 1, pp. 48-55, 2017. 
[2] N. W. Liyanage, R. P. Wijesundera, and K. D. Jayasuriya, "Biodegradable Plantain Pith for Galvanic Cells," Procedings Tech. Sess., vol. 28, no. March, pp. 92-99, 2012, doi: 10.13140/2.1.4432.6080.

[3] E. D. Lustiyati, A. Fitriani, and J. Utari, "Sosialisasi Pengelolaan Sampah Bahan Berbahaya dan Beracun (B3) Rumah Tangga di Dusun Klodran, Padukuhan Sanan, Desa Sendangarum, Minggir, Sleman, DIY," Semin. Nas. UNRIYO, pp. 124129, 2019.

[4] D. Whydiantoro, I. Susandi, Kusumadewi, and A. M. Sidik, "Pengolahan Limbah Kulit Durian Menjadi Bio-Baterai Sebagai Energi Alternatif," J-Ensitec, J., vol. 05, no. 02, pp. 230-236, 2019.

[5] Khairiah and R. Destini, "Analisis Kelistrikan Pasta Elektrolit Limbah Kulit Durian ( Durio Zibethinus ) Sebagai Bio Baterai," Pros. Semin. Nas. Pendidik. FKIP UNTIRTA 2017, pp. 41-44, 2017.

[6] N. Pulungan, M. A. Febria, I. Desma, R. D. Ayuningsih, and Y. Nila, "Pembuatan Bio Baterai Berbahan Dasar Kulit Pisang," Hasanudding Student J., vol. 1, no. 2, pp. 96-101, 2017.

[7] G. A. W. Putra, I. W. Fathona, and Abrar, "Studi Elektroda Berbahan Dasar Jahe (Zingiber Officinale) untuk Aplikasi Superkapasitor Elektrokimia," e-Proceeding of Enginering, vol. 6, no. 1, pp. 1306-1313, 2019.

[8] T. M. Ansari et al., "Essential Trace Metal (Zinc, Manganese, Copper and Iron) Levels in Plants of Medicinal Importance," J. Biol. Sci., vol. 4, no. 2, pp. 95-99, 2004.

[9] Y. Buyang and H. P. Asmaraningrum, "Pengaruh Voltase Dan Waktu Terhadap Pengendapan Logam Mangan Dan Seng Pada Lempeng Tembaga Menggunakan Metode Elektroplating," Magistra, vol. 2, pp. 226-236, 2015. 